\title{
Dynamic Relationship between China and the World: From a Political Economic Perspective
}

\author{
Cunlin Li \\ North Minzu University \\ Camilla H. Wang \\ Shantou University \\ Kathy Tian \\ University of Illinois at Urbana-Champaign
}

\begin{abstract}
The grudges between China and the world have never stopped since British cracked gate of China. The development context between China and the world can be divided into several stages. From "closed door state" to "open to the outside world" under the premise of maintaining China's independence in all fields of politics and economy. It is different from the passive and invading opening to the outside world. Under the general trend of globalization, opportunities and challenges are coexisting. Facing the frequent trade friction, formulating its global strategic view, safeguarding its national interests and homeland security, China adheres to the principle of "one world, one dream" and adheres to the path of peaceful development. The relationship between China and the world is no longer "grudge" but "harmonious coexistence and common development".
\end{abstract}

\section{INTRODUCTION}

There are too many grievances and grudges between China and the world. Of course, the world here does not refer to a single country, but refers to every country that has "disputes" with China. According to the Chinese leadership, China will not oppose to the entire world, nor will she have the capacity to act so. In the international community, the strength of "unity" between nations is extremely powerful, so various alliances have been existing all the time. Some people have said that if it were not for the eight-nation allied forces to fight with China jointly in the same year, it would be very hard for any certain single country to fight with China alone. It is unpredictable that China would not become a semi-colonial country at that time.

The development context between China and the world can be divided into several stages roughly: opening, closing and reopening. Before the Ming and Qing dynasties, the exchanges between China and the world were still frequent. From the Qin Dynasty to the Ming Dynasty, the feudal rule was carried out all the time and it was self-sufficient in the economy, but China was leading the world in terms of the economy and culture at that time, coupled with the enlightened policies that were carried out by the feudal 
ruling class, China made great accomplishments in building her relations foreign countries. Take the prosperity of the Tang Dynasty as an example, at that time, the external traffic was developed very well. The land was centered on Chang'an (Xi' an today). There were lines in the east, the south, and the north, and the western route was the famous "Silk Road." The sea routes extended to Japan and some of the South Asian countries, and lately, moreover, the sea routes even extended to Egypt and East Africa (Zhou, 2000). Under the precondition of convenient transportation, the exchanges between China and foreign countries were also very frequent. In the political world, countries in the world learned the suitable official systems from China and visited China frequently. Economic exchanges were not as comprehensive and frequent as they are now. However, the cultural exchanges involved a wide range of areas, such as the monk Xuanzang's fetching Buddhism Books from India, which opened a window for cultural exchanges between China and India, at same time Japan sent their young men and women to learn the languages and cultures in China (Tian and Dai, 2014).

Therefore, the Tang Dynasty was regarded as the political center, economic center and cultural center in Asia, which had a very high reputation at that time. Many countries' envoys, merchants, scholars, monks kept coming to visit China, traded in China and studied in China. A foreign historian has ever noted: Compared with any other era in Chinese history before the 20th century, the Chinese in the early and middle Tang dynasties were the most confident and receptive to different new things, perhaps it was because China established relations with many Asian countries due to the religions that came from the foreign countries; perhaps it was because many of the clan's giants were barbarian descendants at that time; perhaps it was because China has a strong military force to guard the Silk Road and ensure the smooth flow of business travel. In short, the Chinese in that period were very willing to open themselves up to the world and hoped to get excellent valuables from other countries. All these illustrated that China has already built relations with foreign countries long time ago (He, 2014).

When things go back to the bottom there would be unexpected discoveries. For example, opening to the outside world, many people think that this is the original creation of the Third Plenary Session of the 11th Central Committee of the Communist Party of China. However, when looking back, it turns out that China has had this sprout long ago. Shi Jingqian, a famous sinologist in the United States, addressed in his interview with Time Weekly: "When I taught Chinese language, Chinese history and Chinese culture in the West, I found that there was a flaw in Chinese textbooks, when they mention the modern China History, they always started with the humiliation and aggression suffered by China in the 19th century. When I began to teach Chinese history 40 years ago, I found it very unreasonable. If we want to learn the history of China better, we should start from the China in 17th century, because China was showing a more confident attitude in the world at that time (Zhang, 2011)." Therefore, when studying the grievances between China and the world, it is necessary to mention this period that from the closed-door state to the opening to the outside world. In addition, it should also be mentioned that the historical process from the opening to the closed-door state. Only in this way can people have a complete historical picture of China and the world.

There are many historical reasons for the closed-door state in modern Chinese history. Firstly, the decline of the feudal system and the decadent ruling class, which are also mentioned by many historians or historical textbooks frequently. Secondly, the gap between the economy of its own country (small-scale peasant economy) and the world capitalist economy. During the Ming and Qing Dynasties, capitalism in the world began to sprout due to the rapid development of productive forces. Because the economic foundation determines the superstructure, this sprout also threatened China's original feudal rule. The ruling class was afraid that its own opposition classes would collude with the outside world. At the same time, the world's major capitalist countries started to expand abroad frantically and started the primitive accumulation of capital. As a result, the closed-door policy was the only best policy at that time (Wang and Zhu, 2017).

\section{From the "Closed Door State" to "Open to the Outside World"}

The historical origins of the closed-door state in modern Chinese history could be traced back to the sea ban policy in the early Ming Dynasty. The people should not go to sea and trade with foreigners 
arbitrarily, the coastal ports were blocked, and even the sea-going vessels would be destroyed to cut off the trade with the outside world completely (Shang, 2007). The direct reason for the sea ban policy in the early Ming Dynasty or the policy of "closed-door policy" in the early Qing Dynasty, of course, was to safeguard the domestic domination and prevent invasion. The fundamental reason was still due to China's natural and economic conditions. At that time, China's economy was self-sufficiency, so the foreign trade was almost not required. The sea ban policy of the early Ming dynasty also caused serious problems, which in turn hindered the development of overseas markets and the development of the capitalist sprout and suppressed the primitive accumulation of capital, which made China lag the other major capitalist countries in the world.

Compared with the closed-door policy, the sea ban policy was still light. It only prohibited private offshore trades, it allowed the officials to go to sea to declare the authority of the Ming Empire, for example, the well-known Zheng He's Voyages. The foreign businessmen were also welcomed to China to trade with the Chinese, but the overseas trade must be under the auspices of the official, this is so-called "tribute to trade" (Xue, 2011). In the early Qing Dynasty, it banned overseas trade in an all-round way and practiced "closed-door policy." So why did China's foreign policy become more stringent in the Qing Dynasty? The direct reason is to curb the people's struggle for resistance in the southeastern coastal areas and to prevent the Chinese from colluding with the outside world to form a powerful anti-Qing power. At the same time, to prevent the attacks from the Western colonialists the Qing rulers carried out national defense by using the policy of "closing their doors to their country." However, in our opinion, the most fundamental reason is the poor economy. In the traditional agrarian society that relied on self-sufficiency, the feudal rulers were self-satisfied, China lagged the other countries in the world and excluded all foreign things blindly.

During the Qing dynasty, the sea ban policy had been escalated into the closed-door policy. It was positive for the closed-door policy to prevent foreign aggression and protect the natural economy. However, the result of "self-defense" had hindered the economic and cultural exchanges between China and foreign countries. Also, it hindered the embryonic development of capitalism, the science developments and the social technologies were hindered as well, which resulted in China's lagging far behind the West in modern times (Deng, 2013). Since the Opium War (1848), under the intimidation of the imperialist gunboat, the ports along the eastern coast of China were forced to open through the unequal treaties, namely "open door". Now, the backward and decadent feudal system was unable to resist the advanced capitalist system, coupled with the corruption and compromise of the Qing government. China's door was then forced to open to the outside world. However, it must be emphasized that this type of opening-up is forcibly open, which differs from the current reform and opening. It is a humiliating and inequitable opening to the outside world, and it has brought tremendous disasters to the Chinese people. Starting from the opening of the treaty ports, China was forced to become involved in the capitalist world market and became an appendage of capitalism gradually. As a result, China's natural economy began to collapse, which resulted in the historical change in the modern history of China from "closed-door state" to "opening to the outside world."

From modern China to the founding of the People's Republic of China in 1949, the Chinese people had been bullied by foreign powers and were suffering from the internal trouble constantly. After the founding of New China, the founding leaders faced a catastrophic situation in which not only was the internal society disheveled, but also the remnants of hostility remained stubbornly opposed and vandalized. Therefore, for a prolonged period, China could not open up to the outside world fully. Later, Mao Zedong suggested that China needs to clean the house and then invite guests. With the gradual improvement of the national economy, China seized every opportunity to start its diplomatic activities with the United States, especially with the Soviet Union. Because the socialist camp was led by the Soviet Union and could compete with the United States at that time (Zeng, 2010). After the Second World War, the two opposing camps of socialism and capitalism have been formed in the world. As a socialist country, China is naturally standing on the Soviet side. However, this kind of opening that relied on others will not last too long. Therefore, the following rupture of Sino-Soviet relations caused some difficult outcomes for China. 
It was not until 1978 that the Third Plenary Session of the Eleventh Central Committee of the CPC realized that China took the initiative to open to the outside world truly. Based on independence and selfreliance, following the principle of equality and mutual benefit and mutual trust, China should work with other countries in the world in developing economic cooperation and technology communication (Xu, 2011). This benign opening is a major strategic decision to speed up the socialist modernization and a starting point for setting up a new era of socialist modernization featuring Chinese characteristics. Since the reform and opening, the Chinese economy has then been developed rapidly. China's economy has taken a tremendous stride toward the world and has integrated itself into the economic globalization. Since China adopted the strategy of reform and opening, its achievements have drawn worldwide attention. However, the Chinese pay more attention to the independence of the country. Therefore, opening to the outside world in China is to be under the premise of maintaining its independence in all fields of politics and economy. It is different from the passive and invading opening to the outside world; this point should be emphasized in any means.

\section{"Laughter" and "Tears" of Economic Globalization}

Under the international environment in which peace and development become the theme of the times increasingly, all the countries in the world regard opening to the outside world as one of the important ways for their own development. A country cannot have all the world's advanced technologies and management experience and all resources, but must make up for its deficiencies through opening to the outside world (Lian, 2000). However, the taste of life is never only "sweet" without "bitterness", nor is it only "laughing" without "tears." Economic globalization is just like a taste of life, one knows the taste oneself when living in it.

Economic globalization is a basic trend of economic and social development in the world today and one of the key features of the contemporary world economy. In the World Economic Outlook published in May 1997, the International Monetary Fund put forward the definition of economic globalization: Economic globalization refers to the increase in the scale and form of transnational goods and services transactions and international capital flows, the rapid and widespread dissemination of technology have increased the interdependence of the economies of all countries in the world (Xu, 2006). In view of this, economic globalization has made the world a global village. As the process of world economic globalization is still at an initial stage, its impact on the economies of various countries and the world is unpredictable. However, it is very clear that economic globalization is a "double-edged sword." The benevolent sees the benevolent, the wise see the wisdom, and some economists believe that economic globalization is a favorable progress that can make China becomes richer. However, other economists are skeptical. They point out that if the economic globalization is good, why is the international economy so confused (Chen, 2010)? It is easy to see that there have been many related studies on the pros and cons of economic globalization and it is not necessary to repeat them one by one. Moreover, it needs to be specially explained that what being discussed about here is the relationship between China and the world. Therefore, it focuses on the "laughter" and "tears" that economic globalization brings to China's economy.

Economic globalization is a "double-edged sword" for every country. This is especially true for China. Therefore, economic globalization has provided China with an opportunity to meet the challenges it possesses (Zhou, 2016). In terms of economic development in China, the "benefits" brought by globalization are mainly manifested in the following aspects: Firstly, it is good for China to give full play to China's comparative advantages and to enhance its international competitiveness. Globalization perfected and consolidated a unified world market, it enabled the free flow and optimization of production factors in the world and improved the efficiency of resource allocation. China has comparative advantages in labor forces, resources and market advantages in globalization. Moreover, the comparative advantage of a country is not permanent. Some disadvantages may also be converted positively through exchange and study, and then become advantages. With the progress of economic globalization, China is

in the process of studying and accumulating, and is also forcing China's labor-intensive products to shift to capital-intensive or even technology-intensive products. 
Secondly, the technological proliferation and increase of economies brought by economic globalization and the readjustment of the industrial structure in developed countries are conducive to the improvement of the general manufacturing industry in China. The rapid economic development in the world and the low interest rate policy in developed countries are conducive to attracting foreign investment by the favorable conditions to speed up the economic developments in China (Li, 2005). That is, using foreign investment, the structure of China's exports can be optimized.

Thirdly, globalization has brought the economic relations among countries closer and closer and has made their interdependence be increased highly, it formed a community of interests like "I have you and you have me", and increased humanity's global awareness, cooperation and dialogue, peace and development, which have become the main topic of the times (Yan, 2012). As a result, China's issue will no longer be a mere issue for China. For instance, the issue of environment and trade frictions have become global problems. If they are not resolved, they will directly affect the further development of globalization. Therefore, globalization has also forced the developed countries to consider the problems that China faces and work together to solve them.

Economic globalization is directly promoted by the developed countries. The rules of the game are also governed by the developed countries. As such, the developing countries are the biggest victims of the globalization undoubtedly. China, as the largest developing country was harmed obviously. In the aspect of China's economic development, the "disadvantages" brought by globalization are mainly manifested in the following aspects:

Firstly, due to the various levels of economic and technological development in various countries in the world, it is impossible for them to have equal status and interests in the economic globalization, this is the so-called "arms twist thigh," China is still subject to the developed countries to a certain extent. For example, the developed countries can make use of the cheap local labor and natural resources in China to obtain maximum profits, and occupy the market rapidly by their own advantages and economic strength. In such fierce market competition as jungle and survival of the fittest, China must be at a disadvantage in many aspects.

Secondly, in the field of international direct investments, quite many studies show that the developed countries use economic globalization to transfer their heavily-polluting industries to China through multinational corporations because China's environmental regulations are not as strict as the Western ones. As a result, China is being asked to fulfill more environmental responsibilities under the pressure of all countries in the world. The issue concerning the world environment has become a major topic of the World Economic Forum. The western countries always shirk their responsibilities via diverse ways, and they hope that China will bear more responsibilities and thus there exist all kinds of "China's responsibility theory."

Thirdly, as to the third advantage that was mentioned above, if being viewed from another perspective, will become a disadvantage undoubtedly. Under the slogan of "You have me, I have you," in the western medias, there is also a hidden crisis that may break out at any time. Because with the increase of the interdependence between countries, all countries in the world have formed a chain of "one won then all won, one lost then all lost." Taking the global fiscal crisis that broke out in the United States in 2008 as an example, almost every country was affected by that crisis, which reduced the security of its economy. In addition to the above three points, one more point need to be kept in mind is that economic globalization does not represent "sovereign integration" and the national interests of the country are still above all ( $\mathrm{Li}, 2016)$. In the context of economic globalization, western countries have propagandized that sovereignty has been weakened and the concept of sovereignty has become obsolete. Therefore, it is necessary to make a concrete analysis of these arguments and keep a clear brain always.

Must admit, but also have to be wary of that in the economic globalization, due to different strengths, developed countries and multinational corporations will benefit the most, while developing countries benefit very little. Therefore, the gap between developing countries and developed countries will widen further. Some of the least developed countries will be excluded from economic globalization and become marginalized and even become the modern technology colony of developed countries and multinational corporations. However, it is irreversible whether it brings "tears" or "laughs" from globalization. As a 
developing country, China can only find ways to adapt to it and to work with most countries to establish a fair and orderly new world economic order. The facts of the economic development in the world are clear enough to prove that any country if it has the right development strategy it can succeed in the economic globalization. Why is China doing nothing?

\section{The Continuous Trade Friction}

As China continues to expand its opening up to the outside world and integrate itself into the global economic environment continuously, the contradictions are emerging one after another. China's market economy has not been recognized by the United States and the Europe Union due to frequent occurrence of trade protectionism, trade friction, exchange rate issues and punitive tariffs. After China joined the World Trade Organization, cooperation and friction have become the main topics of China and the world. Moreover, the trade friction that occur in recent years is alarming.

Taking year 2012 as an example, according to the statistics of the Chinese Ministry of Commerce, 77 trade remedy investigations hit China in 2012, involving 27.7 billion U.S. dollars, up $11.6 \%$ and $369 \%$ respectively over the same period of last year. In addition, some scholars think that 2012 was the year when the United States and Europe had the biggest trade friction with China. The United States and Europe have taken "double countermeasures" against China's PV industry successively, almost destroying the industry completely. The above-mentioned "double countermeasures" is an investigation of the antidumping and anti-subsidy investigations conducted by the United States. It is therefore called "double reaction." On the one hand, the United States imposed high punitive tariffs leading to a drastic drop in the scale of exports by $60 \%$. On the other hand, it is a dying catastrophe caused by the pending EU antidumping investigations. China's PV industry has come to a "crossroads."

If the "double reaction" is established, dominoes will be overruled one by one, all industries in the photovoltaic industry chain will be hit hard. The EU's photovoltaic installed capacity accounts for about $70 \%$ of the world's total and the United States accounts for nearly $10 \%$. If both markets close their doors to China, the Chinese PV enterprises will suffer a fatal blow (Chen, 2012). Certainly, Chinese enterprises and relevant departments cannot wait on their death, they can start with the trade dumping in the United States and Europe to see whether they have violated the anti-embezzlement policies of the WTO in the relevant industries, or start with the differences in their market standards and international standards, appeal "double reaction." Only in this way can the U.S. and Europe be reasonably required to give fair treatment to Chinese products.

The trade frictions suffered in 2012 , of course, were far more than the above example that was only a big trade friction. At the China's Foreign Trade Situation Report held on March 23, 2012, the Vice Minister of Commerce Zhong Shan pointed out that China suffered eight trade frictions in the first three months of the year, involving a total amount of 2.28 billion U.S. dollars, compared with the amount in the previous year, it had been increased $80 \%$, China had been the country suffering the most trade frictions during the past 17 years. From late June to now, the "Warning Alert" section on the official website of the Chinese Ministry of Commerce, has been updating the information of foreign trade remedy investigations against China frequently. In addition to the EU's investigation into China's wireless communications equipment and photovoltaic industry, there are also a series of anti-dumping investigations launched by the United States, Brazil and other countries on China's exports of motorcycle tires, seamless steel tubes and passenger car tires. According to the statistics released by the Ministry of Commerce in July, China suffered a total of 40 trade relief investigations, anti-dumping, anti-subsidy and special safeguard measures from 18 countries and regions in the first half of 2012, compared with the same period of last year, it has been increased $38 \%$, and 3.7 billion U.S. dollars involved, $76 \%$ increase compared with the last year. Classified according to the filing countries, the developing countries such as Brazil and India accounted for $70 \%$ of the total number of cases filed. Classified according to the amount involved, the developed countries such as Europe and the United States initiated surveys against China, their amount occupied $60 \%$ of the total.

In 2016, China suffered 119 trade remedy investigations in total initiated by 27 countries (including 91 anti-dumping cases, 19 anti-subsidy cases and 9 safeguard measures). The total amount involved was 
14.34 billion U.S. dollars. The number of cases and the amount involved increased by $36.8 \%$ and $76 \%$ respectively from a year earlier. Nearly half of the trade remedy cases are targeted at Chinese steel products, while the rest are mainly concentrated in the chemical and light industry sectors. In the first 11 months of 2016, China's exports were 12.47 trillion yuan, a decrease of $1.8 \%$. However, the trade friction rose from 98 to 119 (Ma, 2017). Overall, the trade frictions encountered in 2016 in China were characterized by the politicization. It is not known whether China is accustomed to it, or is it common in the western countries. The trade frictions are one after another, and the two sides of the dispute hold their own opinions. In this regard, it is really hoped that the international organizations can have a uniform standard, or at least not so controversial. However, how can the international community give priority to China's interests in the game rules of the international community? Therefore, the rapid development of China's economy is bound to suffer the "courtesy" that other countries have not suffered. The Chinese cannot just accept challenges passively, but also must take the initiative to deal with them.

The Chinese cannot help wondering why there is so much friction between China and foreign countries. In fact, there are many reasons that affect the economic and trade relations between China and the rest of the world. Apart from some purely economic system factors such as trade protectionism, differences in technology and standards, imperfections in the WTO system, etc., the cultural and ideological differences is also one of the reasons, of course, the political needs are also the cause of economic disputes, just like the relationship between the United States and China. The United States is China's largest trading partner, while the United States is also the country that has initiated the largest trade friction with China. This cannot be said to be a mere coincidence. Today, China has become the second largest economic entity in the world, how can the United States, the world's largest economic entity, be unprepared and not vigilant?

The Chinese people fully aware that successive trade frictions were unavoidable phenomenon during the rapid development of China, in the medium and long term, it will become the normal state with the development of China's trade. China is still in a transitional period of integration into the world. China itself is also in a painful period of industrial restructuring, the friction is unavoidable (Yang and Bao, 2017). Both China and the world need to learn from cooperation and understand from friction. Theoretically, the entire world should understand that a stable and rapid economic development in China will be conducive to the development of the world. China is not only belonging to the Chinese but also belonging to the world. Nevertheless, how can this theoretical explanation be understood and accepted by all the countries in the world, especially the current world leader the United States?

\section{China and the World: Dependent on Each Other}

The second decade of 21 th century has already half over, China was developed rapidly in the first 17 years of this century. The level of economic development has been continuously improved. The political system has been continuously improved as well. The overall national strength has risen stably (Cha, 2015). The Chinese are moving forward towards the goal of Building a Well-off Society. Looking around the world, China itself is progressing, while its position in the world has not been raised to what we expect. The 2008 Beijing Olympic Games and the 2010 Shanghai World Expo should be a good opportunity for us to show the world the achievements of China's economic and social development since the reform and opening. We hope that China will be heard more and more in the world and hope that its political, economic and cultural influence on the world will continue to expand. China must become a world leader, especially in the economic field. China's every move may have an impact on the world economy. It is also hoped that the image of a responsible big country can penetrate the hearts of the people in the world gradually. China, who is to be the No.1 in the world, is not only being changed by the world, but also changing the world.

However, it should not think this kind of discussion regarding who changed who or who influenced who, has any real meaning to anyone. In the international exchanges, it is incredible to think that one party is changed by the other party solely. Therefore, the inextricable relations between China and the rest of the world cannot be explained by mere mapping on one single line. From 2001 to 2010, China's exports rose from US \$266,098 million to US \$ 1,577,789 million, an increase of $493 \%$ with an average 
annual increase of $21.9 \%$. While the export trade expanded unprecedentedly, the China's imports was increased as well. The import growth rate is also leading the world. From 2010 to 2015, China's exports to the world was increased from $10.3 \%$ to $13.7 \%$ and the imports was increased from $9.1 \%$ to $10.1 \%$. The global share of service exports increased from 3.9\% to 5.9\%. Especially in 2016, China maintained its strong market demand in the downturn of the world economy. From January to November, China's imports of iron ore and concentrates, copper ore and its concentrates and crude oil increased by $9.2 \%$, $30.5 \%$ and $14.0 \%$ respectively, while imports of integrated circuits increased by $9.3 \%$. Imports of pharmaceuticals and automobiles, the import of spare parts increased by $9.1 \%$ and $8.3 \%$ respectively. From January to October 2017, the import of service trade in China increased by $23.7 \%$. China's substantial growth in imports of international commodities and major industrial products has effectively improved the international supply and demand. It has not only increased the economic growth of resource and energy exporting countries, but has also played an indispensable role in the gradual recovery for the economy of developed industrial countries. Today, China is not only the world's number one export country, but also the second largest importer in the world (Mei, 2011). All in all, the relationship between China and the rest of the world is essentially like a "win-win" mode, and neither side should reject the development of this benign relationship.

China is in the process of modernization. China has rich resources and many successful experiences. However, the internal and external conflicts for China still exist and she needs to face these. All kinds of trade frictions mentioned above and the drawbacks of economic globalization are all worth mentioning. All these are inevitable in the process of development and the Chinese people must face it with confidence. It is hoped that in these conflicts and frictions, everyone should uphold the principle of "one world, one dream," instead of thinking of independence. World peace and development are the blessings for everyone in all countries. Those hegemonies and power politics are doomed to be cast aside and impossible to survive. No matter how hard the future is, China, like the rest of the world, will not be isolated from the rest of the world.

At present, many people, whether they are domestic economists or international economic workers, are optimistic about the development of China and the world. For example, the former Vice President of the World Bank, Lin Yifu, he believes that the new world economic pattern is undergoing qualitative changes. China is playing a huge role in the international fiscal crisis. In the past 30 years or so, with sustained and rapid economic growth in China, it is still possible to maintain its high growth rate in the future and become a new force that will change the pattern of the world economy. The Former World Trade Organization Director-General Mike Moore once said that the WTO without China is not a worldwide trade organization. Yumkhella, the director general of the United Nations Industrial Development Organization, said that China's being added to the WTO benefits not only China itself, but also benefits the developed countries, emerging industrial nations and some of the least developed countries in Africa. After 10 years, China won, the world also won (Guo, 2011). Yes, China won and the world won. However, it is also hoped to see another scenario where the world has won and China has won, despite all the efforts we must make.

Those cooperation or friction we mentioned, they cannot change the close economic relations between China and the world, of course, there will lurk a lot of crises, the close cooperation coexistence with the crisis, this is the specific portrayal of the current and future relations between China and the rest of the world. It is also known that only by opening up can China develop and only by sharing can the world win together.

\section{The Future of China and the World}

Everything should focus on the future to grasp the reality. From 2008 to 2010, the worldwide fiscal crisis originated in the United States accelerated the economic downturn of the West, meanwhile, it is beneficial to the development of China's economy. Because China transformed this global crisis into a crucial and important opportunity for accelerating its own economic development. Chinese enterprises made heroic efforts to develop themselves through their own styles, methods, engineers and senior managements, workers and machinery and equipment. PricewaterhouseCoopers (PwC) report shows that 
China is expected to overtake the United States in 2018, mainly due to the fiscal crisis - it accelerated the transfer of power centers to emerging countries. Goldman Sachs predicts that by 2030, the Chinese stock market will suppress the United States and become the world's first stock market. China will become the world's largest economic entity. China will have global power and influence on five continents. By that time, China will no longer be just China but a powerful China. It will enjoy international prestige, will have modern armed forces and a Moon base (Picarl, 2012). Those predictions, of course, should not be exaggerated, Chinese people may not fully believe it. However, the influences of China to the world is increasing gradually, which is an undisputed topic. However, Chinese people still have some worries about whether China can be recognized by all the countries in the world.

After removing the beautiful exaggerated words, let us imagine the future of China and the world objectively. The world began to examine the issues of real economy and fictitious economy due to the impact from the subprime mortgage crisis in the United States. Let the real economy be developed a little faster, and the fictitious economy, a little bit slower, this was the voice of the public. Due to the subsequent impact of the crisis, the Greece and some other EU countries began to plunge into the sovereign debt crisis, which is now called European Debt Crisis. As one can imagine, the United States and the EU in the future will face a very difficult situation. In the coming decade or so, the major developed countries may enter a period of strategic contraction. At the same time, however, China has enormous potential for development. It is also quite possible to take advantage of such a strategic opportunity to narrow the gap with developed countries in all aspects of economic and social development. Nonetheless, the first problem to be solved is the issues from the new economic growth (Tian and Dai 2014).

It is widely known that before the fiscal crisis, most of the impetus for China's economic development came from import and export, and for a long time China's foreign trade had been favorable balance. However, the external environment China is facing now is very terrible. To reverse this situation, it is necessary to find a new impetus for economic growth in China. The Chinese leaders have proposed to promote the economic growth via stimulating the domestic demand. Therefore, we can predict that in the post-financial crisis era, China will reduce its dependence on external demand in its future economic development. This is not to say that China should be isolated from the rest of the world but should reduce its dependence on the outside world. In addition, China is also likely to be a situation of import and export deficits. This is not a bad phenomenon but a very favorable situation because the future trade deficit can just be offset by the huge trade surplus and thus the large amount of foreign exchange will not be idle.

There are a lot of recent problems with great uncertainty in today's dilemma world. From the closeddoor state to the opening to outside world, from the semi-colonial semi-feudal society to an independent China, during this period, China met too many difficulties. People say it is wonderful in the outside world, but it is helpless as well. The Chinese people have seen too much frustration in the past, and today they have the strength and confidence finally, they have the courage to meet with the outside world, and the ability to digest it, they are respected based on the equal footing, they can tell what is beneficial to them and what may hurt them. In the process of continuous integrating with the world big family, the Chinese have not lost themselves. From the initial "introduction" to the present "going global", the Chinese nation has been adding bricks to its own development with its unique charm, and has been making itself stronger and stronger constantly with the help of external forces (Sun, 2015). The road to opening is not smooth, the Chinese people must make double efforts to realize their goal. The Chinese people do not have to always remember the past, nor indulge in the present. What they must do is to look forward to the future in the longer term.

Neither any country nor any nation can deny that China's peaceful development is a resource and will benefit the world peace and world economic prosperity greatly. On the contrary, if China's economy, politics and society are in turmoil and recession, 1.4 billion people in the world will be suffered. No one wants to see the sufferings. China's development in the future can contribute more lights and warms to the world. Just like the fiscal crisis and the debt crisis in Europe, China is embodying the image of an enormous power. Moreover, if China wants to achieve a great rejuvenation, the Chinese people need to 
pay great attention to any important opportunity whether it is good or bad, why shall they be afraid of it if they are ready?

\section{China's Global Strategy Views}

The Chinese nation has been a nation that loves peace and does not seek expansion since the ancient times. It is therefore a nation that is not aggressive and ambitious. Such a national spirit and cultural tradition have been maintained till now. Under the influence of this national spirit and cultural tradition, the strategies that the historical rulers adopted were focused on how to improve the efficiency of internal rule, and focused on how to consolidate the dominant position. In the field of foreign affairs, they insisted in building high walls to prevent themselves from being attacked by the foreigners. This kind of strategy called "defensive foreign affairs" has become the main idea of the recent China's policies makers, it is termed as defense doctrine (Tian and Dai, 2012).

In the period of human being's lack of effective solution to the long distance and rapid transportation of troops and the fact that human beings have not yet developed strategic long-range attack weapons, defense doctrine was an effective strategic choice for the Chinese nation. However, with the development of social production and science and technology, it is no longer a myth that a country sends troops thousands of miles away within a few minutes, and a deadly attack on the enemy by an army can be operated thousands of miles away. The Gulf War in 1991, the Iraq War in 2003 and 2010 and the Libyan War in 2011 are the best explanations. From a global perspective, when facing this new means of war and armaments, simple defense can hardly be said to be useful. Therefore the "defense doctrine" is not working any more. In other words, any form of defense in contemporary warfare is passive and will result in the failure finally. Precisely because of this, it is a crucial moment for China to abandon this kind of "defense doctrine" and to establish a positive national defense strategy.

When talking about China's establishing the national defense strategy, it does not mean that China must attack the enemy troops first. Instead, China can start attacking the enemy base camps as soon as she is attacked by the enemy, then China can deal a deadly blow to them and annihilate their further strategic offensive until the enemy stops. The Chinese military leadership call this strategy as "positive national defense strategy." The premise for implementing a positive national defense strategy is to establish a correct global strategy first. In the 1960s, Mao Zedong called on people all over the world to unite and fight against the domination by one or two superpowers. This is a global strategy for China during that period. It enabled China to defeat the external attacks and to defend its national interests and national territorial integrity successfully. After the $1980 \mathrm{~s}$, major changes have taken place in the international situation. China abandoned its original global strategy and replaced it with a new international strategy (which in the current authors' view is not a truly global strategy) oriented by seeking the greatest economic benefits. Nowadays the international situation has been changed a lot, due to the unilateralism adopted by the United States, the dark clouds of the Taiwan Strait war have been shrouded in the air through which the hostile forces wanted to make China be an inferior position. Therefore, it is required that China must choose and determine its own global strategy promptly (Lu, 2016).

Mencius was one of the ancient Chinese sages, he said: I am trapped in my heart, I am thinking of what I want to do, then I am going to do...thus I know people survive in disasters and perish in comfort (Mencius, ancient China). On the one hand, China should exercise its utmost patience and sincerity to implement the peaceful unification of the motherland, on the other hand, Chinese people must destroy the plotting to divide the motherland with their own global strategy. China's global strategic layout should be implemented step by step and hierarchically, and should include the following points: public opinion strategy, equipment strategy, base strategy, regional (national) strategy, space strategy, maritime strategy, strategic mobilization and strategic direction, and the strategy for Taiwan, all the above points can be summarized as follows (Tian and Dai, 2014):

- Propagandize China's thought of peaceful development. China should publicize to the entire world the China's national policy of no seeking hegemony, oppose the "China Threat Theory" created by hostile forces, so that the international community will understand China's peaceful development policy. China must do a good job on the American people in public opinion, resist and expose the dehumanization of 
China by the ultra-right forces in the United States, and reduce the "fanned hatred" and misunderstanding that the Americans have. At the same time, China should keep good relations with her European friends, maintain the friendly relations with the African people, make new friends in South America, and resume the friendly exchanges with Japan positively, if necessary, China can make good friends via modern medias, internet and televisions in a certain period.

- Accelerate the development of national defense industry. Faced with the threat posed using ballistic missile defense systems, aircraft carrier battle groups and space-based laser weapons by international hostile forces, China must oppose it and speed up the development of the national defense industry with a focus on the development of long-range and offensive nuclear and air weapons. So, it is necessary to resume heavy industry that had been vandalized because of the agitation of the market, the development of the national defense industry will drive the development of other national economic sectors. This has been illustrated by the U.S. economic history. China should increase investment in the production of productive materials, especially investment in research and education, seize the high ground of information technology and win the high-tech war in the future.

- Do an excellent job building a strategic base. Build many suitable strategic bases for implementing an active defensive strategy. We should consider building a strategic base in mainland China and must choose a correct place for the base scientifically. When possible, consideration should also be given to establishing a strategic base for China outside the country. Being gentle and generous in the international struggle like Confucianism will not work.

- Amending the previous non-aligned diplomatic line. The current international situation is quite different from that of the $1960 \mathrm{~s}$. China should re-examine the international non-aligned diplomatic theory, it cannot be continued mechanically. China should deepen and perfect the "Shanghai Cooperation Organization," and form a strategic alliance with all neighboring countries. Especially, enhance the scientific and technological cooperation with Russia in the defense industry to reduce the national defense pressure cost. China should intensify exchanges with other countries and nations in the world to reduce the resistance when China is forced to implement its unification by non-peaceful means, actually in order to reduce the offensive costs. It is the same in the economic and trade areas, it is necessary to reduce the dependence on one or two countries a little bit, such as the United States, strengthen economic and trade ties with Europe, especially the European Union, reduce foreign exchange reserves in the form of the U.S. dollars and promote the development of science and technology in China with the existing foreign exchange reserves, that is to say, buy the foreign technologies and equipment with those unused foreign exchange reserves.

- Start the space strategic deployment. Information technology and digital technologies have made space a competitive site, the United States and Russia have established their own space forces, so China should establish one as soon as possible. At the same time, it is necessary to speed up the development of the civilian space industry based on the marginalization of space forces, which will not only increase the combat effectiveness of the Chinese army, but also boost the economy of the country.

- Implement the maritime strategy in two levels. The first level is the strategy of cross-harboring 200,000 to 500,000 sails in the Taiwan Strait and defeating the aggressors by the People's War. The second level is the strategy of offshore combating, the ships for ocean-going attacks should be designed in smaller size, fast speed, strong fire and less load. In this way, it will be possible to avoid imitating the old ones designed by other countries in the construction of aircraft carriers because, which will not be able to win at all in the actual battle.

- Establish a strategic mobilization system effectively. The China's peace environment has lasted for more than 20 years. However, the peaceful singing and dancing inside the country cannot eliminate the military threats outside the country. As such, it is necessary to publicize the sense of urgency, get ready for military preparations and establish a national strategic mobilization system. Strategic mobilization should be carried out in the form of strategic reserve at the current stage. Economic development should still be the main content. The methods for implementing it depend on the strategic command arrangements. The strategic commands are mainly focused on the Supreme Commander's wisdom and courage, but also include the composition, the exercise and development of the strategic staff. 
- Strengthen the Taiwan's strategy. The Taiwan issue is the most crucial factor that restricts China's all-round development. As the world knows, the United States has always regarded Taiwan as a neverending huge aircraft carrier in the interests of the Asia Pacific region. Therefore, the United States does not want the mainland to achieve reunification with Taiwan. Taiwan is now much more important than ever to the United States for her global strategic interests. It has become the trump card for the United States to clamp down on China. However, China's sacred territory will never tolerate invasion by foreign forces, only when China completes the reunification can the national rejuvenation be realized. On the one hand, China will never change her attitude toward Taiwan's independence and will make Taiwan's independence unpopular on the Taiwan island. On the other hand, China must deal with the Taiwan issue more pragmatically, support Taiwan's reunification forces and increase the economic and trade contacts with Taiwan, and let Taiwanese people realize that the motherland is the source of Taiwan's well-being. After the above preparations are completed, the Taiwan issue will no longer be a problem. At the same time, the blue-green camp in Taiwan has changed a lot since the communist party and the Kuomintang started their third cooperation. Since Ma Ying-jeou was elected as the leader of Taiwan in 2008, the cross-Strait relations have been heating up and the conflicts have become less than before. The Kuomintang gained historical benefits from its cooperation with the Communist Party and began to escape from gradual decline.

However, since Tsai Ing-wen took office in May 2016, Tsai's "little tricks" have been played constantly and "keeping the current status for the Taiwan Strait" was talked about frequently. Nevertheless, from removing Tsai Sun (Sun Yat-sen) to removing Chiang Kai-shek Kai-shek) he adjusted the class outline of Chinese history into the history of East Asia and other practices, in fact, he was considering to "remove China " in a sneaky way. The Taiwan media's "China Daily" made a statement that the authorities in power want to cut off the blood and historical ties across the Strait through distorted education and cultural policies, which reflect the mentality of promoting the Taiwan's independence and will lead to the political demonstrations across the Strait and the military showdown finally. So, the Taiwan issue must not be taken lightly. It is necessary to step up research and development of national defense high technology to raise the PLA's modern combat capability in an all-round way and prepare for the military struggle. The Chinese people are not afraid to engage in the arms races with Taiwan through which they can destroy the economic foundation of the Taiwan independence forces.

In short, the hostile and sabotaging forces surrounding China are strong and threatening China seriously. China should not adopt any line of appeasement aimed at averting so-called "China threat theory." This is the idea of traitors undoubtedly. On the contrary, China should step up her own national defense construction promptly and destroy the conspiracy that designed secretly. Of course, the specific measures should be more concealed, under the foreseeable premise, the front conflicts with hegemonies should be reduced or avoided so as to ensure that our national defense accelerates its strategy (Wu, 2015). The goal of China's global strategy is to defend its own national security and national interests from being harmed. However, the current hostile forces that can ultimately harm China's national security and national interests have not vanished, they have been assembled publicly. The greater its pace of selfgrowth is, the more it can cause unease among international hostile forces. Driven by the interests of the national states, unilateralism and hegemony will never withdraw from the stage of history automatically. Therefore, China must be vigilant in peace time and based on the awareness to survive in the world.

China's global strategy is not only referring to fighting bravely but also referring to her wisdom, it's a clever combination of these two. In other words, the victory over hostile forces can be controlled via the global strategy. By then, not only will China's people, rich people and rich countries live and work in peace and contentment, but people all over the world will also enjoy the fruits of the victory. Although unilateralism is rampant in the modern world, it is only a wishful thinking and a short-term phenomenon. The direction of the historical wheel has never been reversed by power. Peace and development are the main topics of the current times. Although the new national-state conflicts of interests mentioned above are covered in a wide range and are not able to be controlled, there are many forces that can be used to balance the hegemonies among them. China is a force that cannot be ignored in the stability of world peace. Because after almost 40 years' reform and opening, China has become the second largest 
economic entity and trading nation in the world, the largest foreign exchange reserve country and the most important buyer of the national treasury bonds of the United States (Song, 2010). The peaceful rise of China is conducted in a manner consistent with modern civilization. It is to speed up the rejuvenation of the Chinese civilization during the process of innovation and to represent a great civilized nation in the world.

On April 6, 2017, Chinese President Xi Jinping went to the United States for a summit meeting between China and the United States. This is the first time that the two leaders of both countries have met since Trump became the U.S. President. The two leaders had a friendly and long-time meeting. Both sides spoke highly of the historic progress made in the relations between China and the United States and agreed to promote greater development of Sino-U.S. Xi Jinping emphasized that the good relations between China and the United States are not only beneficial to the two countries but also beneficial to the world. There are one thousand reasons to do an excellent job in Sino-U.S. Relations but no reason to ruin the Sino-U.S. Relations. In the past 45 years since the normalization of Sino-U.S. Relations, the relations between the two countries have enjoyed historic progress despite the ups and downs, bringing tremendous practical benefits to the two peoples. Xi Jinping pointed out: Cooperation is the only correct choice between China and the United States. Our two countries can become good partners absolutely and to make full use of the four high-level dialogues and cooperation mechanisms established by the diplomatic security dialogues, comprehensive economic dialogue, law enforcement and cybersecurity dialogue and social and human rights dialogue, to make a big cooperation cake, develop a list of key cooperation for more early harvest (Cheng, 2017).

However, the Chinese people should keep a clear thinking for a long time that in the current period of rapid changes and restructuring of various economic and political forces in the world, during the historic turning point in the continuous deterioration of the living environment of human beings and under the precondition of the national interests, in the difficult recovery of the world economy, foreign hostile forces are always trying to contain China (Wu, 2012). Not only did the United States and Hong Kong's so-called "New Washington Consensus" of 2006 show continued intentions to contain China, but they still did not forget the "Taiwan Relations Law" during Obama's visit to China in 2009, and he even did not forget to mention the Dalai Lama which has nothing to do with U.S. interests at all, was this implying a deterrent? Therefore, China must not sit back and relax, which is a naive thought of selfdestruction; China must not attack it in all directions. That is a foolish way of self-destruction. It is very important to understand these two points so that China will not be enslaved to the other countries. Instead, China will concentrate on doing an excellent job of economic construction and economic development, at the same time, China will protect her national interests, homeland security unswervingly in all kinds of ways.

\section{CONCLUSION}

From the sea ban policy in the early Ming Dynasty to the closed-door state of Qing Dynasty. Although it has a certain degree of self-defense in preventing overseas aggression and protecting the natural economy, however, the result of "self-defense" had hindered the economic and cultural exchanges between China and foreign countries. Also, it hindered the embryonic development of capitalism, the science developments and the social technologies were hindered as well, which resulted in China's lagging far behind the West in modern times. After the Opium War, under the intimidation of the imperialist gunboat, the ports along the eastern coast of China were forced to open through the unequal treaties, namely "open door". It is a humiliating, unequal open.

After the founding of New China, not only the internal society disheveled, but also the remnants of hostility remained stubbornly opposed and vandalized. Therefore, for an extended period, China could not open up to the outside world fully. It was not until 1978 that the Third Plenary Session of the Eleventh Central Committee of the CPC realized that China took the initiative to open to the outside world truly. Based on independence and self-reliance, following the principle of equality and mutual benefit and 
mutual trust, China should work with other countries in the world in developing economic cooperation and technology communication.

Globalization is a basic trend of economic and social development in the world today and one of the key features of the contemporary world economy. It is a "double-edged sword" for every country. This is especially true for China. Therefore, economic globalization has provided China with an opportunity to meet the challenges it possesses. On the one hand, China has made great progress in the use of its own advantages, and on the other hand, China has been experiencing frequent trade conflicts and conflicts. What is the relationship between China and the world? How to make countries in the world understand that a stable and rapid economic development in China will be conducive to the development of the world?

The Chinese nation has been a nation that loves peace and does not seek expansion since the ancient times, but it does not mean that allow to oppress and being bullied. National interests and homeland security are still the bottom line that can't be touched. China adheres to the path of peaceful development, adhering to the principle of "one world, one dream". China is willing to develop with all the countries of the world.

\section{REFERENCES}

Cha, Z. (2015). Study on the sustainable development of China's economy under the new normal state. Economic \& Trade Practice, 15, 6-7.

Chen, J. (2010). An analysis of the advantages and disadvantages of economic globalization. Journal of International Trade, 8, 70-73.

Chen, W. (2012, August 30). Double reverse or devastated global PV market, experts suggest making the worst plans. China Enterprise News.

Cheng, W. (2017). Cooperation is still the main theme of economic relations between China and the United States. Outlook Weekly, 15, 29-29.

Deng, B. (2013). Analysis of the Reason and Result of the Policy of "closed door state "in Qing Dynasty of China. Technology Management, 14, 68-69.

Guo, L. (2011, December 11). Win-win situation between China and the world-Commentary on the 10th Anniversary of China's Entry into the WTO. Guang Ming Daily.

$\mathrm{He}, \mathrm{R}$ (2014). Study on cultural exchange between China and foreign countries in the Silk Road of the Tang Dynasty. Northwest Agriculture and Forestry University.

Li, J. (2016). Study on the relationship between the market economy and the nation state under the economic globalization. Modern Economic Information, 6, 17-17.

Li, L. (2005). A brief discussion on China's economic development strategy under economic globalization. Utilities Accounting, 4, 14-16.

Lian, D. (2000). The necessity of opening to the outside world from the history of the closed door in our country. Journal of Chifeng University, 6, 16-17.

Lu, D. (2016). The global concept and global strategy of contemporary China. Scientia Geographica Sinica, 4, 483-490.

Ma, J. (2017). The number of China's trade remedy cases reached a historic high in 2016. China Tendering. 3, 12-12.

Mei, X. (2011, September 1). Ten years of China's WTO entry: Winning import and export and boosting the global economy. China Comment.

Pierre P. (2012). 20 years later, China and the world. Jiangsu. PRC: Jiangsu People's Publishing House.

Shang, C. (2007). From the sea ban policy to close the border - On the evolution of the two generation of overseas trade system in the Ming and Qing Dynasties. Journal of Hubei University of Economics, 10, 63-64.

Song, L. (2010). Song Luzheng: The Chinese model creates the greatest miracle in the history of mankind. Social Outlook, 12, 84-86. 
Sun, W. (2015). The basic strategy and strategy of "One Belt, One Road". Macroeconomic Management. 4, 41-43.

Tian, G., \& Dai, Q. (2014). When China Becomes No. 1 What the World will Be? Beijing, PRC: China Fortune Publisher.

Tian, G., \& Dai, Q. (2012). Criticism of Pan-market. Beijing, PRC: China Financial and Economic Publishing House.

Wang, L., \& Zhu, J. (2017). Review of "From closed to open: China early modernization and social transformation". Journal of Historical Science, 3, 121-124.

Wu, F. (2015). The flow of Chinese national image: The origin and evolution of "China threat theory". Social Sciences in Nanjing, 9, 7-16.

Wu, X. (2012). Policy options under the hard recovery of the global economy. Financial Development Review, 21-5.

Xu, G. (2011). Study on Deng Xiaoping 's thought of opening to the outside world. The Party School of the CPC Jilin Provincial Committee.

$\mathrm{Xu}, \mathrm{H}$. (2006). Looking present capitalism's new change and development trend from economy globalization. Journal of Higher Education of South west University of Science and Technology, 4, 24-27.

Xue, E. (2011). The ocean dream cut off by the Empire of Ming dynasty. Business Review, 2, 44-47.

Yan, S. (2012). Analysis and Countermeasures of the advantages and disadvantages of economic globalization. Youth, 6, 213.

Yang, X., \& Bao, Q. (2016). China's economic transition under the new normal-Move steadily in the throes. Bulletin of Chinese Academy of Sciences, 3, 362-375.

Zeng, L. (2010). A brief comment on Mao Zedong's thoughts and practice of opening to the outside world. Journal of China Executive Leadership Academy Jinggangshan, 4, 47-51.

Zhang, R. (2011, December 5). American Sinologist Jonathan Spence: the textbooks of modern Chinese history should not be told from humiliation. Time Weekly.

Zhou, D. (2016). The influence and countermeasures of economic globalization on China's economic development in the new period. Economics, 9, 37-38.

Zhou, S. (2000). The change and influence of the open pattern in the Tang Dynasty. Journal of Henan Normal University (Philosophy and Social Sciences), 1, 5-9. 